NBER WORKING PAPER SERIES

PRIVATE AND PUBLIC INVESTMENTS IN BIOMEDICAL RESEARCH

\author{
Maya M. Durvasula \\ Lisa Larrimore Ouellette \\ Heidi L. Williams \\ Working Paper 28349 \\ http://www.nber.org/papers/w28349 \\ NATIONAL BUREAU OF ECONOMIC RESEARCH \\ 1050 Massachusetts Avenue \\ Cambridge, MA 02138 \\ January 2021
}

We are very grateful to Ryan Broll, Gideon Moore, Maya Roy, and Ralph Skinner for research assistance, and to Bhaven Sampat for very helpful comments. Financial support from NIA grant P01AG005842 (to the NBER), the Alfred P. Sloan Foundation, the Smith Richardson Foundation, and the National Science Foundation Graduate Fellowship Program is also gratefully acknowledged. The views expressed herein are those of the authors and do not necessarily reflect the views of the National Bureau of Economic Research.

At least one co-author has disclosed additional relationships of potential relevance for this research. Further information is available online at http://www.nber.org/papers/w28349.ack

NBER working papers are circulated for discussion and comment purposes. They have not been peer-reviewed or been subject to the review by the NBER Board of Directors that accompanies official NBER publications.

(C) 2021 by Maya M. Durvasula, Lisa Larrimore Ouellette, and Heidi L. Williams. All rights reserved. Short sections of text, not to exceed two paragraphs, may be quoted without explicit permission provided that full credit, including $\odot$ notice, is given to the source. 
Private and Public Investments in Biomedical Research

Maya M. Durvasula, Lisa Larrimore Ouellette, and Heidi L. Williams

NBER Working Paper No. 28349

January 2021

JEL No. I1,O3

\section{ABSTRACT}

Recent policy attention has focused on proposals to reduce prices for drugs that have received public funding. From an implementation perspective, such policies rely on public disclosure of government support for research. In this paper, we highlight two conceptual problems with past attempts to measure these public disclosures, and construct a new data set which corrects for these problems. Our corrected measures suggest that under-reporting of public research support is less of an issue than previously thought.

Maya M. Durvasula

Stanford University

mdurvas@stanford.edu

Lisa Larrimore Ouellette

Stanford Law School

559 Nathan Abbott Way

Stanford, CA 94305

ouellette@law.stanford.edu
Heidi L. Williams

Department of Economics

Stanford University

579 Jane Stanford Way

Office 323

Stanford, CA 94305

and NBER

hlwill@stanford.edu 


\title{
Private and Public Investments in Biomedical Research
}

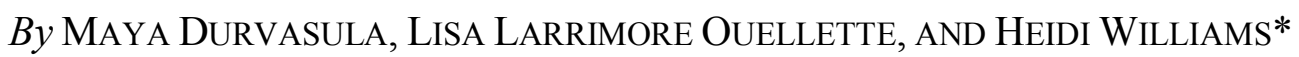

* Stanford University Department of Economics (Durvasula and Williams) and Stanford Law School (Ouellette); Stanford, CA 94305 (maya.durvasula@stanford.edu; $\quad \quad \underline{\text { ouellette@law.stanford.edu; }}$ hlwill@stanford.edu). We are very grateful to Ryan Broll, Gideon Moore, Maya Roy, and Ralph Skinner for research assistance, and to Bhaven Sampat for very helpful comments. Financial support from NIA grant P01AG005842 (to the NBER), the Alfred P. Sloan Foundation, the Smith Richardson Foundation, and the National Science Foundation Graduate Fellowship Program is also gratefully acknowledged.

Many scientific discoveries have roots in both public research support and investment by private firms. Perhaps nowhere are these dual development paths more common than in biomedical research markets. On the more basic research end, the privately funded clinical trials for drugs like Novartis's Gleevec built on decades of government-funded research on gene mutation and cell-signaling. ${ }^{1}$ On the more applied research end, Moderna's SARS-CoV-2 vaccine has received heavy financial support from both the US National Institutes of Health (NIH) and the Biomedical Advanced Research and Development Authority (BARDA), building on substantial private funding to develop its mRNA platform. ${ }^{2}$

\footnotetext{
1 See Azoulay et al. (2019) for more on this example.

2 See Sherkow et al. (2020) for more on this example.

3 See Contreras (2020) for more on one example of reasonable pricing agreements, which were briefly imposed by the US NIH in response to controversy over the pricing of novel drugs for AIDS. In 1999, Representative Sanders introduced a bill (H.R. 626) that would have required institutions developing new drugs based on federally funded research to enter into reasonable pricing agreements with the
}

In recent years, much public debate has focused on policies to reduce prices for drugs that have received public funding, such as through reasonable pricing agreements. ${ }^{3}$ In practical terms, implementation of such policies relies on public disclosure of government support for research. Under the 1980 Bayh-Dole Act, recipients of federally funded research grants must include a statement in the text of any resulting patent applications referencing the granting agency and the specific grant number to provide notice that the government has certain rights in the invention (including a nonexclusive license). ${ }^{4}$ Previous work by the Government Accountability Office (GAO 1999) and Rai and Sampat (2012) has argued that these "government-interest statements" are underreported. However, two conceptual problems have plagued past attempts to gauge the extent of this under-reporting.

First, "certificates of correction," issued by the US Patent and Trademark Office (USPTO)

Secretary of Health and Human Services. Sampat (forthcoming) places these modern-day debates in a historical context.

${ }^{4}$ More precisely, Bayh-Dole states that federal funding agreements must contractually require grant recipients to include this information in patent applications and to execute nonexclusive licenses confirming the government's rights in the invention; see 35 U.S.C. $\$ 202$ (c)(6) and 37 C.F.R. $\S$ 401.14(f). Some funding agencies also imposed this reporting requirement before Bayh-Dole. 
to address mistakes in patent grants, can add disclosures of public funding to existing patents. GAO (1999) mentions this possibility in passing, and James Love - with the nonprofit Knowledge Ecology International (KEI) - has documented three examples of such corrections adding public funding disclosures. For example, KEI publicized an 18-year lag between the approval of a patent on a drug developed by Novartis and the addition of a correction disclosing public funding (KEI 2017; Love 2019). However, to the best of our knowledge this phenomenon has not been systematically investigated. ${ }^{5}$

Second, several legal and regulatory sources suggest that disclosures of public funding in "parent" patents apply to derived continuation ("child") patents. This suggests that simple counts of government-interest statements in continuation patents may lead to an underestimate of public funding disclosures.

In this paper, we construct new data which allows us to shed light on two key questions about public funding disclosures in the sample of patents linked to drugs approved by the US Food and Drug Administration (FDA). First,

\footnotetext{
5 Love analyzed certificates of correction between 2000 and 2015, but did not break out certificates of correction related to disclosure of public funding (Love 2017).

6 Patents are recorded in the so-called Orange Book (the FDA's Approved Drug Products with Therapeutic Equivalence Evaluations) but are removed when they expire, so constructing a complete set of patents from the Orange Book requires reconstructing a list from each
}

how common are public funding disclosures via certificates of correction or parent-induced coverage of continuations? Second, do these two channels appear to be quantitatively important in assessing the completeness of public funding disclosures? We close by highlighting some key policy issues that emerge from our analysis.

\section{Data construction}

Our data construction combines publicly available administrative records and datasets from the USPTO, the FDA, and the NIH to document patterns in public research support for all new drugs ("new molecular entities") approved by the FDA from 1981 to 2014. For each of the 638 drugs approved over this period, we collect data about the drug's approval path from FDA records and measure patents associated with the drug using the FDA's Orange Book. ${ }^{6}$

Following Sampat and Lichtenberg (2011) and building on the methodology in de Rassenfosse et al. (2019), we identify all patents granted between 1981 and 2020, including all patents listed in the FDA's

annual version of the publication. One of us (Williams) digitized the historical Orange Book patent and exclusivity tables for years 19852016 (no Orange Book was published in 1986), based on PDF versions obtained via a Freedom of Information Act (FOIA) request; that data is available here: https://www.nber.org/research/data/orange-bookpatent-and-exclusivity-data-1985-2016. Since Orange Book patent listings began in 1985, we are unable to determine if drug patents were listed and removed before 1985 . 
Orange Book, that include government-interest statements. $^{7}$ As in Sampat and Lichtenberg (2011), we also identify all patents assigned to federal agencies.

We use USPTO records on patent continuations to link "parent" patents to derived, continuation patents. Additionally, we use the USPTO's corrections file to identify Orange Book patents with certificates of correction. As certificates of correction are only available as scanned image files on the USPTO website, we hand-reviewed all correction image files published for patents in our sample in order to note which certificates of correction pertained to government-interest statements.

As an independent source of public funding disclosures, following Rai and Sampat (2012), we collected records published in the NIH's RePORTER data. ${ }^{8}$ Starting in 1985 , this dataset lists all patents reported by grant recipients as the outputs of NIH-sponsored research (but not research conducted in NIH labs).

In total, we thus analyze four measures of public research support:

1. Patent disclosure: Drug has $\geq 1$ Orange Book patent disclosing a government-

\footnotetext{
${ }^{7}$ In particular, we search for government-interest statements in all Orange Book patents granted in or after 1981. As Footnote 6 clarifies, we do not observe patents that were de-listed from the Orange Book before 1985. Note that the Bayh-Dole Act took effect on July 1, 1981; patents based on contracts entered into before this date were not subject to these disclosure requirements.
}

interest statement (following Sampat and Lichtenberg 2011)

2. "Corrected" patent disclosure: Drug has $\geq$ 1 Orange Book patent disclosing a government-interest statement, including in parent patents and corrections published by the USPTO

3. NIH disclosure: Drug has $\geq 1$ Orange Book patent disclosed in NIH RePORTER

4. Agency disclosure: Drug has $\geq 1$ Orange Book patent assigned to a federal agency

\section{Measuring public research support}

In our sample of 5,187 Orange Book patents, $90(1.73 \%)$ include a governmentinterest statement. However, as described above, this figure fails to account for public funding as disclosed through either certificates of correction or parent-induced disclosures for continuation applications.

While a substantial share of the patents in our sample $-1,975$ patents, or $38 \%$ of our sample - are linked to one or more certificates of correction, only 19 patents are linked to a certificate of correction that adds a government-interest statement to the patent text. ${ }^{9}$ While this correction hence affects a

\footnotetext{
8 See Appendix for a more detailed description of the NIH RePORTER data.

${ }^{9}$ We identify seven additional certificates of correction that alter the text of an existing government interest statement. In each of these cases, revisions either add details about the relevant funding agencies or alter the reported grant numbers.
} 
small number of patents as a share of our sample $(0.37 \%)$, it is worth noting that this correction is nonetheless substantial relative to the (low) measured rate $(1.73 \%)$ of government-interest statement disclosures included in the original patents.

In addition to disclosures through certificates of correction, several legal and regulatory sources suggest that disclosures of public funding in "parent" patents apply to derived continuation ("child") patents, which are separate patents based on the same disclosure and priority date as their parent. First, child applications expressly incorporate the specification of parent applications by reference. Second, Federal Circuit caselaw indicates that if a parent patent application is licensed, then there is an implied license to continuations, which should apply to government interest statements as well. ${ }^{10}$ Third, informal guidance from the NIH states that continuation patents do not need a separate confirmatory license of government rights if the parent patent is licensed. ${ }^{11}$ In our sample we identify 15 patents linked to a governmentinterest statement through disclosure in a parent application. As with the certificate of

\footnotetext{
10 See Cheetah Omni LLC v. AT\&T Services, Inc., 949 F.3d 691 (Fed. Cir. 2020), and Endo Pharmaceuticals Inc. v. Actavis, Inc., 746 F.3d 1371 (Fed. Cir. 2014).

11 Specifically, within iEdison - the platform that helps government grantees comply with the Bayh-Dole Act - patentees need to use a "confirmatory license" to confirm that the US government has
}

correction adjustment, this parent disclosure pass-through affects a small number of patents as a share of our sample $(0.21 \%)$, but the correction is not insignificant compared to the low measured rate of government-interest disclosures.

In order to investigate whether these two channels - certificates of correction and parentinduced disclosures - appear to be quantitatively important in gauging the completeness of public funding disclosures, we use patents reported to the NIH as the output of sponsored research as a point of comparison.

We identify sixteen patents in our sample which are reported in the NIH RePORTER data, but which do not directly include a government-interest statement. All sixteen report government funding through either a certificate of correction, a parent patent, or both. Specifically, twelve had certificates of correction that alter the text of the original patent to include a disclosure of NIH funding, and six are continuations of parent patents that include government-interest statements. Two of the sixteen patents fall in both categories.

Of course, some patents benefitting from public funding may neither include a

a nonexclusive license to the invention, and the NIH advises: "Only one Confirmatory License is needed if filed on the first patent in the series (except CIP [continuations-in-part]). Confirmatory Licenses flow down the patent record and do not flow up the patent record." See slide 81 here: https://regionalseminars.od.nih.gov/phoenix2019/wpcontent/uploads/2019/10/Intellectual Property-An In-

Depth_Look at Bayh-Dole_and_Reporting_Requirements.pptx. 
government-interest statement nor be reported to the NIH RePORTER data. However, with that caveat in mind, our analysis suggests that under-reporting of public research support may be less of an issue than previously thought.

Table 1 tabulates summary statistics on the share of drugs receiving public research support based on each of our measures. As we discuss more below, even though our corrected patent disclosure measure has a higher mean, the share of drugs reporting public support based on these measures is nonetheless quite small - around 8 percent.

\begin{tabular}{|c|c|c|c|}
\hline & All drugs & $\begin{array}{c}\text { Standard } \\
\text { review }\end{array}$ & $\begin{array}{l}\text { Priority } \\
\text { review }\end{array}$ \\
\hline $\begin{array}{l}\text { \# of new } \\
\text { molecular } \\
\text { entities }\end{array}$ & $\begin{array}{c}683 \\
(100 \%)\end{array}$ & $\begin{array}{c}403 \\
(59.0 \%)\end{array}$ & $\begin{array}{c}280 \\
(41.0 \%)\end{array}$ \\
\hline $\begin{array}{l}\geq 1 \text { patent } \\
\text { disclosure }\end{array}$ & $\begin{array}{c}44 \\
(6.44 \%)\end{array}$ & $\begin{array}{c}17 \\
(2.49 \%)\end{array}$ & $\begin{array}{c}27 \\
(3.95 \%)\end{array}$ \\
\hline $\begin{array}{l}\geq 1 \\
\text { corrected } \\
\text { patent } \\
\text { disclosure }\end{array}$ & $\begin{array}{c}52 \\
(7.61 \%)\end{array}$ & $\begin{array}{c}21 \\
(3.07 \%)\end{array}$ & $\begin{array}{c}31 \\
(4.53 \%)\end{array}$ \\
\hline $\begin{array}{c}\geq 1 \mathrm{NIH} \\
\text { patent } \\
\text { disclosure }\end{array}$ & $\begin{array}{c}32 \\
(4.69 \%)\end{array}$ & $\begin{array}{c}14 \\
(2.05 \%)\end{array}$ & $\begin{array}{c}18 \\
(2.64 \%)\end{array}$ \\
\hline $\begin{array}{c}\geq 1 \text { patent } \\
\text { assigned to a } \\
\text { federal } \\
\text { agency }\end{array}$ & $\begin{array}{c}10 \\
(1.46 \%)\end{array}$ & $\begin{array}{c}10 \\
(1.46 \%)\end{array}$ & $\begin{array}{c}0 \\
(0 \%)\end{array}$ \\
\hline
\end{tabular}

TABle 1: MeAsures OF PubliC SuPPORT FOR New Drugs Approved By THE FDA, 19812014

Notes: Table reports four measures of public funding for FDA-approved drugs. The sample consists of 683 new drugs ("new molecular entities") approved by the FDA from 1981 to 2014. We split these drugs by FDA review pathway (priority or standard). All drugs approved before 1992 are designated as standard review.

\section{Conclusions}

We close by highlighting some key policy issues that emerge from our analysis.

First, a natural question is whether additions of public research disclosures via certificates of correction reflect - at least in some cases strategic behavior on the part of applicants. Testing for such behavior is beyond the scope of this paper, but as a step in that direction we compare the timing of corrections to Orange Book patents which add government interest statements $(n=19)$ and those that alter other aspects of the patent text $(n=2,604)$. On average, government interest statement corrections were made 77 months ( $\sim 6.4$ years) after patent grant, compared to 46 months $(\sim 3.8$ years) for other types of corrections. Figure 1 plots cumulative density functions for each type of correction. While impossible to draw any firm conclusions from this descriptive figure, future work investigating this issue seems warranted. The fact that federal law 
currently gives patent holders "reasonable time" (nebulously defined) to disclose funding seems perhaps more ambiguous than is ideal.

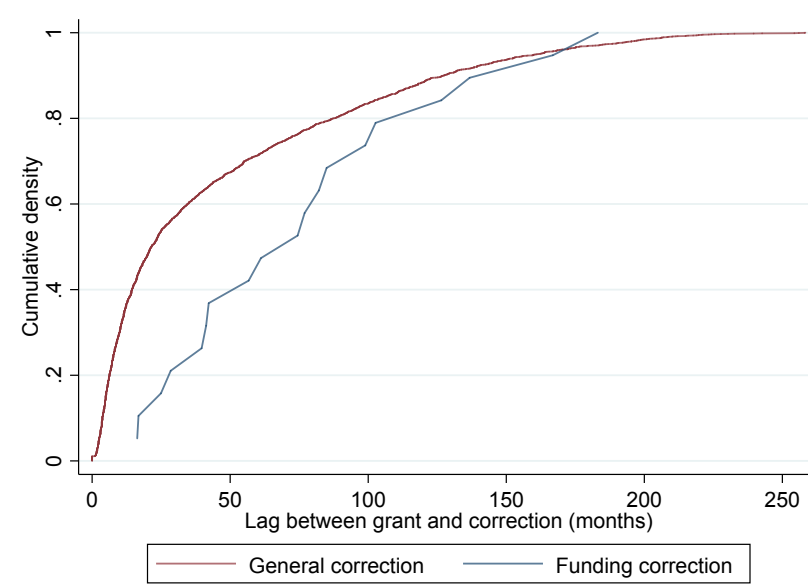

Figure 1: LAG TIME FOR CORRECTIONS TO ORANGE BOOK PATENTS

Notes: Figure is a cumulative density function that reports time between patent grant and approval of USPTO certificate of correction for 2,623 corrections on 1,976 Orange Book patents. We separate "general" corrections from corrections to government interest statements.

Second, a key policy goal of the patent system is public disclosure of information. As stressed by James Love and KEI in their investigation of specific corrections to government interest statements (e.g. KEI 2017), the fact that certificates of correction are not integrated into standard patent data sets makes these corrections "invisible" for many of the intended users of patent data. Similarly, more clearly disseminating information on parent-induced disclosures for continuation applications may be warranted.

Third, it is important to emphasize that our measurement exercise in this paper is not meant to estimate the contribution of public research funding to biomedical research. Such an analysis - as is undertaken by Azoulay et al. (2019) - would need to account not just for the narrowly defined government interest statements analyzed here, but also for the multitude of indirect mechanisms through which public research funding contributes to biomedical research advances.

Finally, from a broader policy perspective, our analysis makes clear that even though our corrected patent disclosure measure increases the share of drug patents acknowledging public research support, the share of drugs acknowledging public support based on our corrected measures is nonetheless quite small around 8 percent. Based on this count, the US government has direct patent rights related to only a small share of FDA approved drugs, and even among those, a minority of Orange Book patents are exclusively public. ${ }^{12}$ This suggests that from a practical perspective, policies 
aimed at leveraging these direct patent rights as a way of controlling drug prices will necessarily be limited in scope. Moreover, from a conceptual standpoint we would argue that the questions of which drugs or which diseases to target with public research subsidies is - and should be - distinct from the question of how to encourage access to existing drugs, and that policy debates should not conflate these two goals as ones that need to be solved jointly (Hemel and Ouellette 2019).

\section{REFERENCES}

Azoulay, Pierre, Joshua Graff Zivin, Danielle Li, and Bhaven Sampat. 2019. "Public R\&D investments and private-sector patenting: Evidence from NIH funding rules," Review of Economic Studies 86(1): 117-152.

Contreras, Jorge. 2020. "What ever happened to NIH's 'fair pricing' clause?" Bill of Health blog.

De Rassenfosse, Gaetan, Adam Jaffe, and Emilio Raiteri. 2019. "The procurement of innovation by the U.S. government," PLoS ONE 14(8): e0218927.

Hemel, Daniel J. and Lisa Larrimore Ouellette. 2019. "Innovation Policy Pluralism," Yale Law Journal 128: 544 - 614.

Knowledge Ecology International. 2017. "Penn 'Certificates of Correction' on Federal Funding for 5 CAR T Patents," KEI blog.
Love, James. 2017. "Errors in patent grants: More common in medical patents," Bill of Health blog.

Love, James. 2019. "Novartis, Dana Farber, Oregon Health \& Science University Wait 18 Years to Disclose NIH Funding in Key Gleevec Patent," Bill of Health blog.

Rai, Arti and Bhaven Sampat. 2012. "Accountability in patenting of federally funded research," Nature Biotechnology 30: 953-956.

Sampat, Bhaven. (Forthcoming). "The government and pharmaceutical innovation: Looking back and looking ahead," Journal of Law, Medicine, and Ethics.

Sampat, Bhaven and Frank Lichtenberg. 2011. "What are the respective roles of the public and private sectors in pharmaceutical innovation?" Health Affairs 30(2): 332-339.

Sherkow, Jacob, Lisa Larrimore Ouellette, Nicholson Price, and Rachel Sachs. 2020. "How does Moderna's COVID-19 vaccine work, and who is funding the development?" Written Description blog.

US Government Accountability Office. GAO; 1999. Technology Transfer: Reporting Requirements for Federally Sponsored Invention Need Revision. 